\title{
First record of Phloetribus opimus Wood (Coleoptera: Curculionidae: Scolytinae) on cultivated Ficus carica L. in Morelos, Mexico
}

\author{
Elizabeth De los Santos-García', Víctor López-Martínez ${ }^{1}$, Armando Burgos-Solorio², \\ Dagoberto Guillén-Sánchez ${ }^{1}$
}

\begin{abstract}
Phloetribus opimus Wood (Coleoptera: Curculionidae: Scolytinae) is reported for the first time from fallen wood of cultivated fig (Ficus carica L.) in Morelos, Mexico.
\end{abstract}

KeYWORDS

bark beetle, fig tree, host association

RESUMEN

Se reporta por vez primera a Phloetribus opimus Wood (Coleoptera: Curculionidae: Scolytinae) de madera de higo cultivado (Ficus carica L.) en Morelos, México.

Palabras clave

escarabajo descortezador, higo, asociación de huésped

\footnotetext{
${ }^{1}$ Posgrado en Ciencias Agropecuarias y Desarrollo Rural, Facultad de Ciencias Agropecuarias Universidad Autónoma del Estado de Morelos (UAEM), Av. Universidad 1001, Col. Chamilpa, 62209, Cuernavaca, Morelos, México.

${ }^{2}$ Centro de Investigaciones Biológicas (UAEM).

*Autor para correspondencia: victor.lopez@uaem.mx
}

Fecha de recepción: 29 de octubre de 2018.

Fecha de aceptación: 21 de enero de 2019.

Disponible en línea: 28 de julio de 2019.

The cultivated fig tree, Ficus carica L. (Moraceae), is a growing crop in Mexico, with 1507.95 ha cultivated, $52.8 \%$ of which is cultivated in Morelos (797.5 ha) (SIAP 2018), with a slow but constant surface expansion rate. Surprisingly, data on F. carica pests is limited. Reports include shot and stem borers (Bautista et al. 2003, López-Martínez et al. 2015) and Drosophilidae fruit flies (Bautista et al. 2017).

In cultivated fig tree orchards, pruning is a traditional agronomic activity. This practice is conducted for phytosanitary purposes and to induce vegetative growth (Kumar 2014, Maimon 1988). But incorrect wood elimination (figure 1) has a potential consequence: having wood debris acting as a valuable xylophagous and phleophagous reservoir (Siitonen 2001).
While conducting xylophagous studies on cultivated Ficus in Morelos, Mexico, many specimens of undetermined scolytinae were collected from fallen pruned branches (figure 1). This allowed us to identify this material at the species level and generate data for technicians and farmers recognition. Until now, none scolitine species have been recorded from cultivated fig trees from Morelos.

Material was preserved and mounted with standard techniques, determined with Wood (1982) keys. Pictures of adult specimens were taken with a DXM 1200C Nikon camera attached to a SMZ 1500 stereomicroscope and edited with image processing software (Image tools 3.0 and Adobe Photo Shop CS6 v13.0 Extended). 
All specimens were determined as Phloetribus opimus Wood, 1969 (Coleoptera: Curculionidae: Scolytinae), a small bark beetle collected in Mexico and Central America (Atkinson et al. 1986, Wood 1969 and 1982, Wood and Bright 1992).

\section{Phloetribus opimus Wood, 1969.}

Material examined: 224 specimens, MEXICO: Xalostoc, Morelos, madera colectada [fallen wood], 28/V/2017, E. De los Santos G., 18.7317 -98.9182, specimens emerged in laboratory on several dates: 29/V/2017, 30/V/2017, 31/V/2017, 1/VI/2017, 6/VI/2017, 8/VI/2017，9(VI/2017，10/VI/2017，16/VI/2017，17/ $\mathrm{VI} / 2017 ， 19 / \mathrm{VI} / 2017 ， 20 / \mathrm{VI} / 2017 ， 23 / \mathrm{VI} / 2017 ， 25 /$ $\mathrm{VI} / 2017 ， 4 / \mathrm{VII} / 2017 ， 25 / \mathrm{VII} / 2017 ， 26 / \mathrm{VII} / 2017 ， 27 /$ VII/2017，8/VIII/2017，9/VIII/2017，10/ VIII/2017，11/ VIII/2017, 24/VIII/2017, 25/VIII/2017, 26/VIII/2017, 31/ VIII/2017，1/IX/2017, 3/IX/2017，5/IX/2017，7/IX/2017, 9/IX/2017, 30/IX/2017, 3/X/2017, 10/X/2017, 15/X/2017, 18/X/2017, 20/X/2017, 25/X/2017, 27/X/2017, 1/XI/2017, 6/XI/2017，11/XI/2017，15/XI/2017，21/XI/2017， 25/ XI/2017, 28/XI/2017, 30/XI/2017, 2/XII/2017, 8/XII/2017, 10/XII/2017, 15/XII/2017, 18/XII/2017, 21/XII/2017, 23/ XII/2017，26/XII/2017，29/XII/2017，2/I/2018，5/I/2018， 8/I/2018， 11/I/2018，16/I/2018，19/I/2018，22/I/2018， 26/I/2018, 28/I/2018, 2/II/2018, 6/II/2018, 10/II/2018, 13/ II/2018, 17/II/2018, 20/II/2018, 23/II/2018, 26/II/2018, $1 /$ III/2018, 4/III/2018, 10/III/2018, 16/III/2018, 20/III/2018, 27/III/2018，30/III/2018，4/IV/2018，10/IV/2018， 16/ $\mathrm{IV} / 2018 ， 18 / \mathrm{IV} / 2018 ， 21 / \mathrm{IV} / 2018 ， 24 / \mathrm{IV} / 2018 ， 29 /$ $\mathrm{IV} / 2018 ， 4 / \mathrm{V} / 2018 ， 8 / \mathrm{V} / 2018 ， 12 / \mathrm{V} / 2018 ， 81 / \mathrm{V} / 2018$, 26/V/2018, 8/V/2018.

Phloetribus opimus (figure 2) is regarded as a potential pest of exotic and native Ficus species, with a 2-ramification-horizontal gallery (Atkinson et al. 1986), causing mild damage to branches of living trees (Atkinson et al. 1986). Other host records are uncertain (Wood 1982). Its role as a pest on F. carica is still undetermined, but the present report confirms its preference for this host genus. Fallen branches are part of a common bad pruning practice in local cultivated fig trees, which farmers and technicians ought to improve to reduce alternative substrate for this and other wood feeding insects.

On the other hand, this is the first scolitine species recorded from F. carica in the country, providing new data on phytophagous fauna associated to this fruit crop. Characterizing local fauna is the best opportunity to develop integrated management strategies.

\section{ACKNOWLedgments}

We would like to express our appreciation to Conacyt, for providing Elizabeth De los Santos-García (No. 606521) with a graduate scholarship. This work is the result of a collaboration between the Cuerpo Académico Producción Agrícola (UAEM CA-074) and Entomología y Fitopatología (UAEM CA-073).

\section{REFERENCES}

Atkinson TH, Martínez-Fernández E, Saucedo-Céspedes E, Burgos-Solorio A. 1986. Scolytidae y Platypodidae (Coleoptera) asociados a selva baja y comunidades derivadas en el estado de Morelos, México. Folia Entomológica Mexicana 69: 41-82.

Bautista N, Hernández LM, Llanderal C. 2003. Insectos de importancia agrícola poco conocidos en México. Colegio de Postgraduados. Montecillos, México.

Bautista N, Illescas CP, López E, Velazquez LJ, García CdeJ. 2017. Presence of Drosophilidae (Diptera: Ephydroidea) flies associates with fig fruits in Morelos, Mexico. Florida Entomologist 100(4): 813-186. https://doi. org/10.1653/024.100.0409

Kumar R, Ganesh S, Chithiraichelvan R, Upreti KK, Sulladmath VV. 2014. Effect of spacing and pruning on growth, yield and quality of cv. Deanna fig (Ficus carica L.). Journal of Horticultural Sciences 9(1): 31-37.

López-Martínez V, Vargas OR, Alia-Tejacal I, Toledo-Hernández VH, Corona-López AM, Delfín-González $\mathrm{H}$, Guillen-Sánchez D, Jiménez-García D. 2015. Xylophagous beetles (Coleoptera: Buprestidae and Cerambycidae) from Ficus carica in Morelos, Mexico. The Coleopterists Bulletin 69(4): 780-788. https://doi.org/10.1649/0010-065X-69.4.780

Maimon A. 1988. The optimal density and fig tree (Ficus carica L.) pruning for a breba crop in Israel. Acta Horticulturae 480: 133-136. https://doi.org/10.17660/ActaHortic.1998.480.22

[SIAP] Servicio de Información Agroalimentaria y Pesquera [internet]. 2018. Anuario Estadístico de la Producción Agrícola. [cited 14 July 2018]. Available in: http://nube. siap.gob.mx/cierreagricola/

Siitonen J. 2001. Forest management, coarse woody debris and saproxylic organisms: Fannoscandian boreal forests as an example. Ecological Bulletins 49: 11-41. https://doi.org/10.2307/20113262

Wood SL. 1969. New records and species of neotropical bark beetles (Scolytidae: Coleoptera), aprt IV. Brigham Young University Science Bulletin 10(2): 1-46.

Wood SL. 1982. The bark and ambrosia beetles of North and Central America (Coleoptera: Scolytidae), a taxonomic monograph. Great Basin Naturalist Memoirs 6: 1-1553.

Wood SL, Bright SE. 1992. A catalog of Scolytidae and Platypodidae (Coleoptera), part 2. Taxonomic Index. Great Basin Naturalist Memoirs 13: 1-1553. 


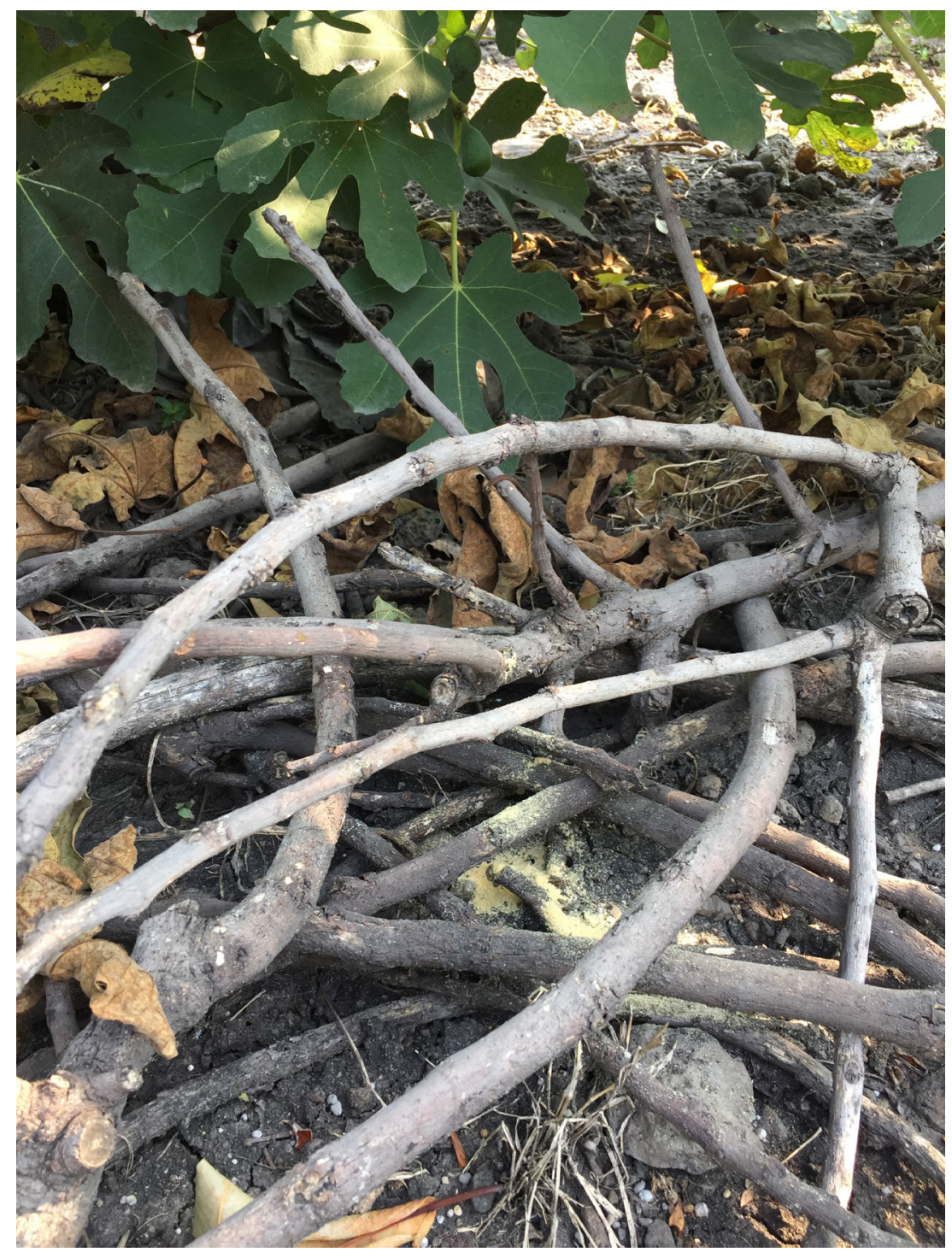

Figure 1. Wood debris accumulated in F. carica orchards, with symptoms of xylophagous feeding activity.
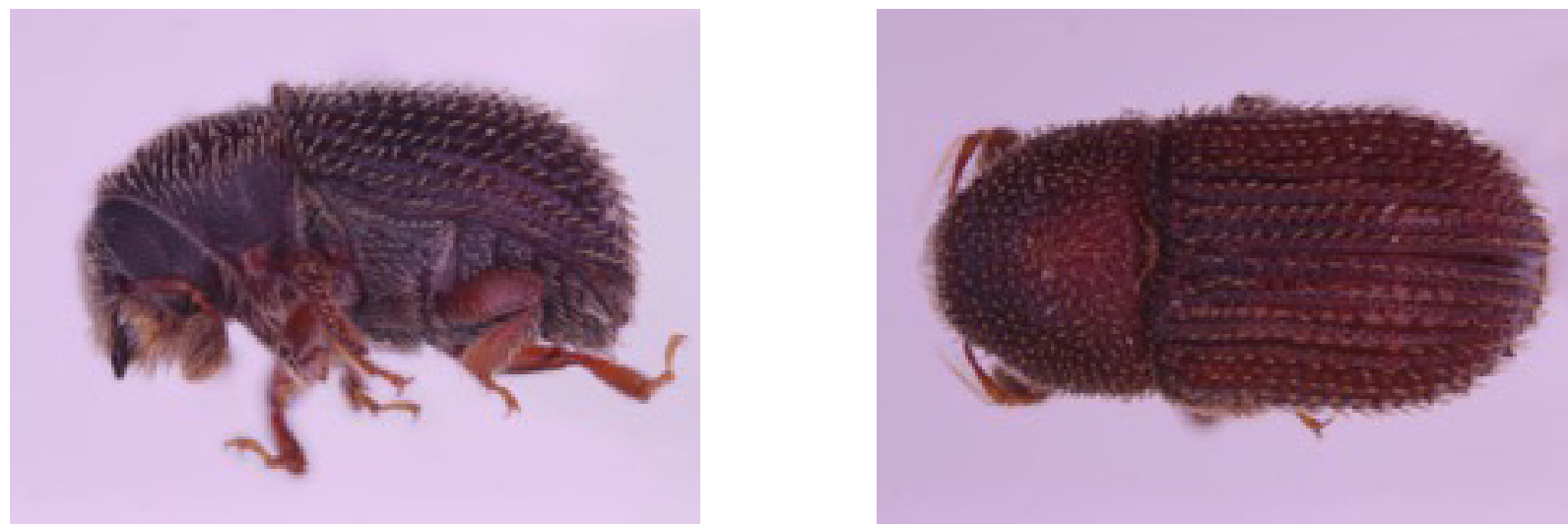

Figure 2. Male habitus of Phloeotribus opimus Wood (Coleoptera: Curculionidae: Scolytinae, lateral view [left], dorsal view [right]). 